\title{
389. Diagnostik und Therapie des Thoraxtraumas
}

\author{
W. Wagner, H. Groitl, B. Husemann, H. D. Kamp, P. Schepke und N. Wolf \\ Chirurgische Klinik mit Poliklinik der Universität Erlangen-Nürnberg (Direktor: Prof. Dr. F. P. Gall), \\ D-8520 Erlangen-Nürnberg, Institut für Anästhesiologie der Universität Erlangen-Nürnberg \\ (Vorstand: Prof. Dr. E. Rügheimer), D-8520 Erlangen
}

\section{Diagnosis and Therapy of Thoracic Trauma}

Summary. Thoracic trauma is often diagnosed too late, treated too late and therefore associated with a too high mortality. A total of 570 in-patients (1.1. 1978 to 30.9 .1982$)$ have been evaluated statistically. The most common cause was a road traffic accident $(58.4 \%)$. There were additional extra-thoracic injuries in $50.2 \%$. The most common injuries were fractures of the ribs $(72 \%)$ combined with haemato-pneumothorax. By improving emergency care, including shortening transport time and maintaining strict respiratory support, the mortality rate in combined thoracic injuries was decreased from $34 \%$ to $17 \%$. However, simple thoracic trauma is still associated with a mortality of between $6 \%$ and $9 \%$.

Key words: Thoracic trauma - Diagnosis - Therapy - Mortality.

Zusammenfassung. Ein Thoraxtrauma wird oft zu spät erkannt, zu spät behandelt und hat daher eine zu hohe Letalität. Die Unterlagen von 570 stationären Patienten (1. 1. 1978 bis 30. 9. 1982) wurden statistisch ausgewertet. Häufigste Ursache ist ein Verkehrsunfall $(58,4 \%$ ). Extrathorakale Begleitverletzungen lagen in $50,2 \%$ vor. Häufigste Verletzungsfolge sind Rippenfrakturen $(72 \%)$ in Kombination mit Hämato-Pneumothorax. Durch Verbesserung des Rettungswesens mit kurzen Transportzeiten und konsequenter Atemtherapie konnte die Letalität beim kombinierten Thoraxtrauma von 34 auf $17 \%$ gesenkt werden. Das isolierte Thoraxtrauma hat dagegen eine gleichbleibende Letalität von 6 bis $9 \%$.

Schliisselwörter: Thoraxtrauma - Diagnostik - Therapie - Letalität.

\section{Korrekturosteotomie an der unteren Extremität}

\author{
M. Roesgen, E. Ludolph und J. Heusgen
}

Berufsgenossenschaftliche Unfallklinik Duisburg-Buchholz, Großenbaumer Allee 250, D-4100 Duisburg

\section{Corrective Osteotomy of the Leg}

Summary. Corrective osteotomies are presented in cases of post-traumatic abnormal position of the leg. The indication and technique of osteotomy as well as the technique of osteosynthesis with internal fixation or external clamps are discussed. The localisation of the osteotomy and the aim of the correction give the following classifications: 1 . pertrochanteric: correction of valgus or varus position; 2 . femur shaft: rotation and lengthening; 3. condyles of femur and 4. tibia head: correction of valgus or varus position; 5 . tibia shaft: correction of axis. The development is documented until bone healing has occurred. Principles of osteotomy are shown.

Key words: Corrective osteotomy - Indication - Technique - Results.

Zusammenfassung. Typische Korrekturosteotomien posttraumatischer Fehlstellungen der unteren Extremität werden aufgezeigt. Indikation und Technik der Osteotomie sowie die Osteosynthese mit innerer und äußerer Fixation werden differenziert. Einteilung der Osteotomie nach Höhe und Korrekturziel: 1. pertrochantär: Valgus- und Varuskorrektur, 2. Femurschaft: Rotations- und Längenausgleich, 3. percondylär und 4. Tibiakopf: Valgus- und Varuskorrektur, 5. Tibiaschaft: Achsenkorrektur. Die Verlaufsserien werden bis zur Ausheilung dokumentiert. Die Prinzipien der Osteotomien werden abgeleitet.

Schliisselwörter: Korrekturosteotomie - Indikation - Technik - Ergebnisse. 